KAVAKA 55:36-38(2020)

doi:10.36460/Kavaka/55/2020/36-38

\title{
Effect of Carbon Nutrition on the vegetative growth of Cylindrocladium parvum
}

\author{
C. Manoharachary \\ Department of Botany, Osmania University, Hyderabad-500007, Telangana \\ Corresponding authorEmail:cmchary@gmail.com \\ (Submitted on October 20, 2020; Accepted on December 12,2020)
}

\begin{abstract}
Cylindrocladium parvum P. J.Anderson is known to cause leaf spot disease on Eucalyptus sp. collected from Bhadrachalam. This pathogen has not been worked out for its carbon nutritional requirements. Therefore, an attempt has been made to study the efficacy of Glucose and Fructose (Monosaccharides), Maltose and Sucrose (Disaccharides) on the growth and sporulation of this pathogenic fungus. Fructose was found to support highest growth in comparison to other monosaccharide and disaccharide sugars evaluated.

Keywords: Cylindrocladium parvum, disaccharides, Eucalyptus monosaccharides, carbon nutrition.
\end{abstract}

\section{INTRODUCTION}

Fungi are known to grow and multiply on different habitats in which the nutrient sources such as carbon, nitrogen, and others are available. Therefore, the study of nutrition of individual fungi is of paramount importance unless the substrate supplies all the nutrients all the time. Fungi maintain their individuality in their choice of specific nutrients for their growth. Fungi need about 17 elements available in the form of specific compounds as ions and free elements. In spite of many interesting inferences drawn so far still lacunae exist between the facts and conclusions. Carbohydrates and their derivatives have generally been found to be the most widely utilizable sources of carbon, both in nature and under laboratory conditions. Therefore, in this investigation, carbon as a source of nutrition has been considered. Monosaccharides can easily assimilate and are available to the fungal organisms. Fungi differ widely in using different sources of monosaccharides such as glucose and fructose and disaccharides such as maltose and sucrose (Cochrane, 1958; Steinberg, 1950; Lilly and Barnett, 1981; Tandon, 1967; Jayasekhar and Muthuswamy, 2001; Vahidi et al., 2006; Hamad et al., 2014; Dutta and Das, 2017) for their growth and development and in the production of varied types of metabolites. It is also observed that among the available carbon sources, glucose is the most efficient growth promoter followed by sucrose for many of the fungi. Maltose and fructose are also considered equally good sources of carbon as for growth and development of fungi is concerned(Held, 1970; Singh and Tandon, 1970).

In the present study, carbon requirement of Cylindrocladium parvum P.J. Anderson, the leaf spot pathogen of Eucalyptus sp., have been worked out as there has been no available data on this pathogen on this aspect.

\section{MATERIALS AND METHODS}

The pathogen, Cylindrocladium parvum was isolated from infected leaf of Eucalyptus sp. The cultures have been raised on full strength Potato Dextrose Agar (PDA ) medium and single spore cultures of pathogen were raised. Four days old culture was used as inoculum in the study of carbon nutrition (Fig. 1 \& 2)

In the present investigation, glucose of the basal medium is substituted with fructose, sucrose and maltose. In this experiment, the four liquid media, namely Potato dextrose, Potato sucrose, Potato maltose, and Potato fructose were used. All these liquid media were sterilized in autoclave for $1 / 2$ and hour at $21 \mathrm{lb}$. Pressure.

In all these media 20 grams of carbon source has been added to $1000 \mathrm{~mL}$ of medium. Four days old test fungus was used for inoculation. $50 \mathrm{~mL}$ of different liquid media are taken in 100 $\mathrm{mL}$ conical flask and are inoculated with the mycelia disc of the test fungus. Three replications for each treatment are kept and incubated at room temperature $\left(30^{\circ} \mathrm{C}\right)$. Potato sucrose liquid medium was used as a basal medium. Observations were taken on seventh day and fourteenth day, respectively. It is important to mention here that instead of using Czepeks medium, Lilly and Barnett medium and others, the naturally available Potato extract along with distilled water and added source of carbon have been used so as to see the impact of these media which have not been worked out earlier.

After the growth of fungus at the end of seventh day and fourteenth day, the dry weights of the fungal mycelium was taken by filtering the fungal growth through Whatman filter paper \#44 and the mycelia biomass were dried in an oven at

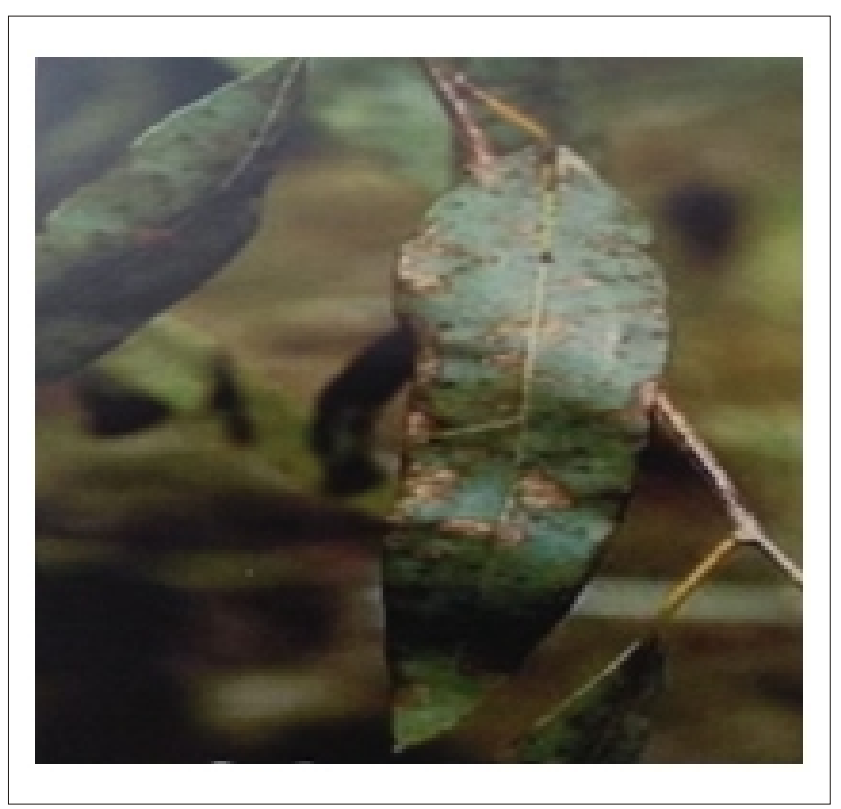

Fig. 1 Infected leaf 


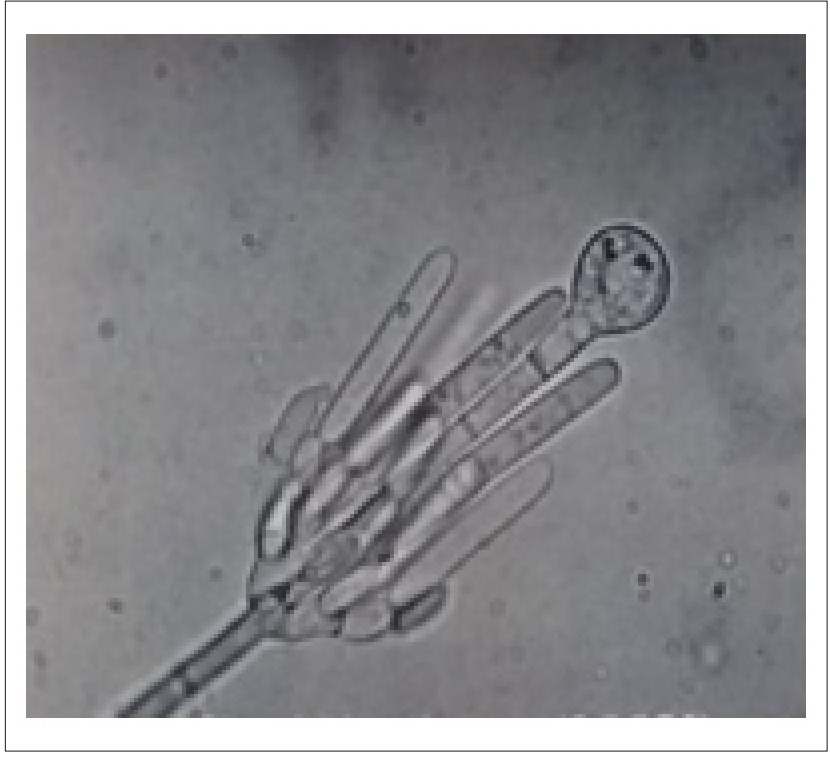

Fig. 2 Conidiophore (200X)

$60^{\circ} \mathrm{C}$ for 24 hours followed by recording their dry weights, respectively.

\section{RESULTS AND DISCUSSION}

Mycelia dry weight yield in mg attained after seventh and fourteenth day of incubation together with $\mathrm{pH}$ changes of the culture media are presented in Table 1 and Fig 3. Among all the sugars tested fructose was found to give highest growth of mycelia biomass, but statistically all the sugar sources were found at par showing insignificant differences between the performance of fungal mycelium in these sugars. Control without carbon source showed no fungal growth. Therefore, it is clear that Cylindrocladium parvum can be grown by supplying with any one of the above sugars as carbon source. Monosaccarhides such as glucose and fructose are easily assimilable. As per the earlier workers fructose seems to be efficiently used by many fungi and similar observation has been found in the present study (Hasija, 1970; Tandon, 1967).

Fungi exhibit carbon heterotropy and obtain their carbon requirement from various organic sources. A variety of organic compounds are utilitized by fungi and the nature of

Table 1. Effect of Carbon sources on dry matter yield of Cylindrocladium parvum

\begin{tabular}{|c|c|c|c|c|c|c|c|}
\hline $\begin{array}{l}\text { Carbon } \\
\text { Source }\end{array}$ & $\begin{array}{c}\text { Initial } \\
\text { pH }\end{array}$ & $\begin{array}{c}\text { Days of } \\
\text { Incubation }\end{array}$ & $\begin{array}{c}\text { Dry weight } \\
\text { of the } \\
\text { mycelium in } \\
\text { mg. }\end{array}$ & $\begin{array}{c}\text { Final } \\
\text { pH }\end{array}$ & Reaction & $\begin{array}{c}\text { Sporuia- } \\
\text { tion }\end{array}$ & DMRT \\
\hline Glucose & 4.0 & $\frac{77}{15}$ & $\begin{array}{l}20.0 \\
32.0\end{array}$ & $\begin{array}{l}5.2 \\
7.0\end{array}$ & $\begin{array}{l}\text { Alkaline } \\
\text { Alkaline }\end{array}$ & $\begin{array}{c}++ \\
++\end{array}$ & $\mathrm{a}$ \\
\hline Fructose & 4.0 & $\begin{array}{c}7 \\
15\end{array}$ & $\begin{array}{l}35.0 \\
39.0\end{array}$ & $\begin{array}{l}5.1 \\
4.8\end{array}$ & $\begin{array}{l}\text { Alkaline } \\
\text { Alkaline }\end{array}$ & + & $\mathrm{a}$ \\
\hline Sucrose & 4.0 & $\begin{array}{c}7 \\
15\end{array}$ & $\begin{array}{l}29.0 \\
32.0\end{array}$ & $\begin{array}{l}5.4 \\
5.5\end{array}$ & $\begin{array}{l}\text { Alkaline } \\
\text { Alkaline }\end{array}$ & $\begin{array}{c}++ \\
++\end{array}$ & $\mathrm{a}$ \\
\hline Maltose & 4.0 & $\begin{array}{c}7 \\
15 \\
\end{array}$ & $\begin{array}{l}25.0 \\
30.0 \\
\end{array}$ & $\begin{array}{l}3.5 \\
3.6 \\
\end{array}$ & $\begin{array}{l}\text { Acidic } \\
\text { Acidic } \\
\end{array}$ & $\begin{array}{l}- \\
+\end{array}$ & $\mathrm{a}$ \\
\hline Control & 4.0 & $\begin{array}{c}7 \\
15\end{array}$ & $\begin{array}{c}5.0 \\
10.0\end{array}$ & $\begin{array}{l}5.0 \\
5.2\end{array}$ & $\begin{array}{l}\text { Alkaline } \\
\text { Alkaline }\end{array}$ & - & $\mathrm{b}$ \\
\hline $\begin{array}{l}\text { Significant } \\
\text { (Dry weigh } \\
\text { Sporulatior }\end{array}$ & $\begin{array}{c}\mathrm{D} 0.05 \% \\
\mathrm{o} \text { the } \mathrm{M} \\
+++ \\
++ \\
+ \\
+\end{array}$ & $\begin{array}{l}=10.16 \\
\text { celium in mg } \\
\text { Indicates } \\
\text { Indicates } \\
\text { Indicates } \\
\text { Indicates }\end{array}$ & $\begin{array}{l}\text { Oml media) } \\
\text { nore sporulatio } \\
\text { verage sporula } \\
\text { ess sporulation } \\
\text { il sporulation. }\end{array}$ & & & & \\
\hline
\end{tabular}

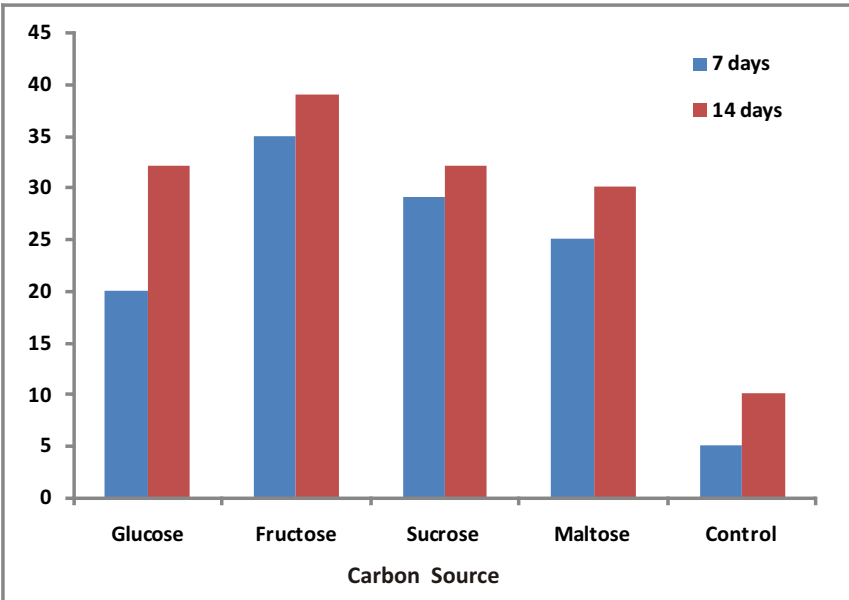

Fig 3: Histogram showing Effect of Carbon Source on Dry Matter Yield of Cylindrocladium parvum.

the organism largely determines the range of substrate. The differences observed among the utilization of various sugars by Cylindrocladium parvum may be due to presence or absence of specific enzyme(s) necessary for the growth. Structural variation and configuration of the molecules of different carbon sources also play an important role (Cantino, 1949; Lilly and Barnett, 1951).

\section{CONCLUSION}

In conclusion the pathogen Cylindrocladium parvum parasitizing Eucalyptus spp. is known to utilize different carbon sources efficiently. Of the various carbon sources evaluated, fructose was a growth determinant and this data forms new information for this pathogen as it has not been worked out.

\section{ACKNOWLEDGEMENT}

The author is thankful to NASI, Prayagraj, India for their encouragement

\section{REFERENCES}

Cantino, E.C. 1949. The nutrition of Colletotrichum gloeosporioides Penz. Amer. J. Bot. 36: 95-112.

Cochrane, V.V. 1958. Physiology of Fungi. John Wiley \& sons. Inc. NY pp. 524.

Dutta, D. and Das, M.D. 2017. Effect of carbon and nitrogen sources on mycelial biomass and biosynthesis of antifungal protein from Aspergillus giganteus MTCC 8408 in submerged fermentation. Journal of Scientific and Industrial Research 76 (6): 369-375.

Held, A.A. 1970, Nutrition and fermentative energy metabolism of the water mold Aqualinderella fermentans. Mycologia 62: 339-358

Jayasekhar, M. and Muthuswamy, M. 2001. Effect of Carbon and Nitrogen sources on the growth of Phytophtora capsci. Madras. Agric. J. 87 (7/9):482-483.

Lilly, V. G. and Barnett, H. L. 1951. Physiology of the Fungi. 
Mc Graw Hill Book Co. Inc. London \& New York, pp. 464.

Hamad, H.O., Alma, M.H., Ismael, H. M. and Goceri, A. 2014. The effect of some sugars on the growth of Aspergillus niger. KSUJ. Nat. Sci. 17 (4): 7-11.

Hasija, S.K., 1971. Physiological studies of Curvularia. pallescens. Nova Hedwigia 19 (3-4): 551-558.

Singh, B. P. and Tandon, R. N. 1970. Utilization of monosaccharides by two pathogenic species of Curvularia. Acad. Sci. India.36B: 199-204.
Steinberg, R.A. 1950. Growth of fungi in synthetic nutrient solutions. II. Bot. Rev. 16: 208-228.

Tandon, R.N. 1967 Presidential Address, 54th ISCA, Botany: 1-14.

Vahidi, H., Mojab, F. and Taghavi, N. 2006. Effect of carbon sources on growth and production of antifungal agents by Gymnopilus spectabilis. Iranian Journal of Pharmaceutical Research $\mathbf{3}: 219-222$. 